\title{
A New Method of Assessing the Effects of a Service- Learning Class on Engineering Undergraduate Students
}

\author{
Patricia Maloney \\ Assistant Professor \\ Dept. of Sociology, Anthropology, and Social Work \\ College of Arts and Sciences \\ Texas Tech University \\ Lubbock, TX 79409 \\ patricia.maloney@ttu.edu
}

\author{
Lauren Dent \\ Research Assistant \\ Dept. of Sociology, Anthropology, and Social Work \\ College of Arts and Sciences \\ Texas Tech University \\ Lubbock, TX 79409 \\ lauren.dent@ttu.edu
}

\author{
Tanja Karp \\ Associate Professor, Department of Electrical and Computer Engineering \\ Whitacre College of Engineering \\ Texas Tech University \\ Lubbock, TX 79409 \\ tanja.karp@ttu.edu
}

Abstract - Increases in engineering service learning courses and enrolled undergraduates necessitate further research and recommendations concerning the assessment of student learning and growth. Assessment of such growth may be difficult in service learning courses because of the types of skills it fosters: interpersonal skills, critical thinking, and other professional skills not easily tested for in a classroom. Some previous attempts at assessment were predominantly standards-based and designed to measure what researchers thought students should gain from the course, rather than being based in what students thought. In this paper, we first ask students what skills they learned in service learning, determine their thoughts about the usefulness of different kinds of assessment, and then use their words to construct a naturalistic assessment that can serve as a pre- and post-test to measure growth in engineering service learning courses. The data come from 96 students and three semesters of a service learning section of a large Introduction to Engineering course at a large state university. Overall, we conclude that students perceive that they have grown at statistically significant levels in communication skills, teamwork, leadership, time management, and other engineering skills noted below. We argue that student perceptions of growth matter for their persistence in engineering and resilience after professional or academic setbacks.

Index Terms: Assessment, Professional Skills, Service Learning, Student Perceptions

\section{INTRODUCTION}

In the past few decades, service learning (SL) has entered engineering programs as a method of teaching students content matter, a way for students to connect their knowledge with "real world" applications, and as a means to engender interest in and knowledge about STEM fields in their local communities. ${ }^{\mathrm{i}, \mathrm{ii}}$ This push to include SL in curricula and engage with the local community is certainly present in both engineering as a discipline ${ }^{\text {iii,iv }}$ and at many universities like our large state university, Texas Tech University. To fulfill this need at our university, there is a SL section in the large undergraduate Introduction to Engineering course that began in 2011 and continues today (2013). This section (usually around 40 students a year) works with local 
grade school students to prepare them for an eight week long LEGO Robotics competition that occurs annually.

However, even though students at our university almost uniformly report verbally and in course evaluations that they have benefitted from engaging in SL, the actual assessment of the particular ways and amount in which they have benefitted has been difficult to determine. Other assessment tools like the standards-based NESLOS, ${ }^{\mathrm{v}, \mathrm{vi}}$ while certainly helpful, did not fully encompass the ways in which the undergraduates in this sample reported being affected by SL or provide the means to determine how much SL had changed them over the course of a semester. Thus, in this paper, we have used the undergraduates' own thoughts to authentically develop an assessment to determine how our SL section was affecting them. This assessment can be used alone or in conjunction with other assessment tools. The examination of student perception is invaluable as a research tool as it allows for the instructional aspects of SL to respond to the students' perceived strengths and weaknesses that inevitably shape their academic, social, professional and personal progress. In some cases, instructors may choose to change or personalize the assessment to their engineering SL courses.

Our specific research questions are:

1. What skills do undergraduate engineering students believe that they will need in their careers? Does their assessment of themselves on those skills change over the course of a semester in a SL course, thus suggesting a connection between SL and later professional success? To what elements in this SL course do students attribute those changes?

2. What were the student perceptions of the differing types of assessment used in this course and the effects of those assessments? Can we use their perceptions and the findings from research question one to form a standardized assessment tool that is portable to other universities with similar engineering SL classes, or make recommendations for how engineering SL should be assessed in other universities?

First, we briefly discuss the background of our program in order to provide context to our results, as well as the germane literature about the history of SL and assessment in SL. In that section, we additionally discuss the importance of student reflections and self-perception in the pedagogy of undergraduate learning. Next, we describe our research and analysis methods, followed by our results (divided by research question). Finally, we conclude with an assessment tool based on our results that may aid others wishing to assess the efficacy of engineering SL courses on undergraduates.

\section{BACKGROUND AND PREVIOUS RESEARCH}

\section{Course Structure and Service Learning Assignment}

The SL course is part of a three student-credit-hour Introduction to Engineering course with the purpose of providing an "introduction to the engineering profession, including the distinction between different majors, engineering problem solving, MATLAB programming, Excel basics, professionalism and ethics, and experiences in team design projects."vii It addresses the following educational objectives as defined by ABET $^{\text {viii }}$ in Criterion 3: Student Outcomes: 
(a) an ability to apply knowledge of mathematics, science, and engineering

(c) an ability to design a system, component, or process to meet desired needs

(e) an ability to identify, formulate, and solve engineering problems

(f) an understanding of professional ethical responsibility

(g) an ability to communicate effectively

(k) an ability to use the techniques, skills, and modern engineering tools necessary for engineering practice

The course is typically taken by students during their first year at Texas Tech who are calculus ready. The student body consists of students from different engineering degree programs, preengineering students, transfer students from community colleges, and a small number of nonengineering students, since this course fulfills the State of Texas' Core Technology and Applied Science requirement. Every semester, several sections of this course are offered and, since 2011, every spring semester one section has officially been offered as SL section, identifiable through an " $\mathrm{S}$ " in the section number. This section has been taught by one of the authors. Experience has shown that students enrolling in this section are typically not aware of the meaning of " $\mathrm{S}$ " in the section number. After explaining the SL assignment at the first class meeting, a small number of students make use of the opportunity to switch to a different section of the course.

The SL happens during 15 hours of mentoring local grade school teams participating in an annual 8 week long LEGO robotics challenge offered by the Edward E. Whitacre Jr. College of Engineering as part of its outreach and community engagement mission. ${ }^{\text {ix }}$ The challenge is open to all grade school teams in the region at no cost. It uses the LEGO MINDSTORMS kits, and the robots designed from these kits need to autonomously accomplish a given number of annually changing challenges within a two minute time limit. School teams are coached by a teacher and work on their robot design at their school either during special class periods or after school. They visit the university campus three times: once for a kick-off event in February when the annually changing challenge is revealed and schools receive their free game pieces and game mats, once in March for a trial run under similar conditions as the final competition, which is the third event held in April.

The majority of the SL is done at the schools, but students also accompany their school teams to the on-campus events. At the beginning of the semester, each student picks a school that fits his/her schedule and available means of transportation. During the 8 week SL, students experience their teams go through the various steps of the engineering design process such as brainstorming, experimental design, project scheduling, testing and evaluation, and trouble shooting and improving.

After each mentoring session, typically once or twice a week, students are required to document their experience in a journal and connect it to the course learning outcomes. The evaluations of skills important in the field of engineering given at the beginning and end of the semester are other course assignments aimed at having the students reflect about their learning experience. Last, students are asked to relate the design method observed at the schools to the engineering design process explained in class.

To prepare students for their SL experience, the LEGO NXT MINDSTORMS kits are used for in-class activities. At the beginning of the semester, students learn principles of computer programming through the NXT-G software environment. Throughout the semester the LEGO kits are used in the course, e.g. to acquire data that is then used for statistical analysis, (mean, standard deviation, histograms), graphical representation of experimental data, or an 
introduction to calculus when deriving instantaneous velocity and acceleration from distance measured over time. Students also have access to a set of LEGO NXT MINDSTORMS kits and the NXT-G software at the university library, so that they can solve problems encountered during the mentoring session at the school. For more information on the course and how it fulfills the selected ABET a-k objectives mentioned above, refer to the course syllabus and previous research by Karp. ${ }^{\mathrm{x}, \mathrm{xi}}$

\section{History and Effects of Service Learning}

The National Service-Learning Clearinghouse (NSLC) defines SL as "a teaching and learning strategy that integrates meaningful community service with instruction and reflection to enrich the learning experience, teach civic responsibility, and strengthen communities."xii SL is a pedagogical approach developed in response to a history of educational philosophy which supports learning that goes beyond rote instruction, or what we may think of as a traditional instructor-student method of learning. Other such pedagogies include cooperative learning, active learning, problem-based learning, collaborative learning and undergraduate research. All of these pedagogies focus on student learning that engages students in an experiential way, such that learning becomes the responsibility of the student, rather than the instructor.

As early as 1900, John Dewey, whose philosophies on education remain influential today, promoted the integration of students into society, regarding the social aspects of learning with utmost importance. In his work, School and Society, he writes, "When the school introduces and trains each child of society into membership within such a little community, saturating him with the spirit of service, and providing him with the instruments of effective selfdirection, we shall have the deepest and best guarantee of a larger society which is worthy, lovely, and harmonious."xiii

Dewey, like many before him, and scores of educators who would follow him, supported what scholars refer to as cooperative education. Johnson et al. ${ }^{\text {xiv }}$ have developed the classroombased elements of cooperative learning, asserting that this type of learning benefits students when it includes (1) Positive Interdependence (2) Individual Accountability (3) Promotive (Faceto-Face) Interaction (4) Interpersonal and Small Group Skills and (5) Group Processing.

Another pedagogical approach following in this tradition of student-centered learning, Problem-Based Learning (PBL), developed by the McMaster University Faculty of Health Sciences, has historically been implemented in medical school curriculum, however has important similarities to, and implications for, SL. Barrows ${ }^{\mathrm{xv}}$ cites the "McMaster" PBL characteristics as follows: (1) Learning is student-centered, (2) Learning occurs in small student groups (3) teachers are facilitators or guides (4) problems form the organizing focus and stimulus for learning (5) Problems are a vehicle for the development of clinical problem-solving skills (6) New information is acquired through self-directed learning.

Barrows and Tamblyn ${ }^{\mathrm{xvi}}$ explain problem based learning as "learning that results from the process of working toward the understanding or resolution of a problem." The application of PBL to the medical student is one that supports his or her ability to effectively apply knowledge gained in medical school to the "problem" presented in the form of a diagnostics and general patient care. PBL forces students to develop their problem solving skills, and has "two educational objectives: the acquisition of an integrated body of knowledge related to the problem, and the development or application of problem-solving skills"xvii 
The applications of these teaching pedagogies to SL are direct and easily incorporated. Bringle $^{\mathrm{xviii}}$ suggests that "service-learning represents a paradigm shift in higher education because it heightens the role that students can assume as constructors of knowledge. Furthermore, service learning shifts the role of the instructor from the center of instruction to the facilitator of learning that occurs outside the classroom". Other trends that paved the way for SL, like collaborative learning which took the focus away from the instructor-pupil paradigm, and PBL which forced students to identify and solve their own problems in the field, inevitably shaped what service-learning would and has become. These trends encouraged the elements of SL that make it what it is today: socially integrated learning, working in the field, and working to solve real problems directly, rather than hypothetical ones in the classroom. Bringle ${ }^{\mathrm{xix}}$ writes that "part of the strength of service learning is illustrated in its compatibility with other pedagogical trends in education, such as collaborative learning, problem-based learning, and diversity education."

Across disciplines, SL is widely known to have a positive impact on the academic and personal lives of students. In an exhaustive review, Eyler at al. ${ }^{\mathrm{xx}}$ have compiled mounting evidence from136 articles which implicates that SL facilitates experiential lasting knowledge resulting in positive personal outcomes, ${ }^{\text {xxi,xxii }}$ social outcomes, ${ }^{\text {xxiii, xxiv }}$ learning outcomes, ${ }^{\text {xxv,xxvi }}$ career development, ${ }^{\text {xxvii,xxviii }}$ and relationships with institutions. ${ }^{\text {xxix, xxx,xxxi }}$

\section{Assessment in Service Learning}

Since the effects of SL encompass both content knowledge/technical skills as well as harder to measure professional skills such as communication, leadership and interpersonal skills, it can be difficult to determine how to fully assess student growth. Additionally, in some cases, there may be a self-selection effect: those individuals who know that they are signing up for a SL course may differ in ways that are difficult to control for with standard assessment techniques (such as course exams or written assignments). Thus, assessment in SL is challenging, and as a result, much of it has been designed to be institutionally or program specific. That is, discrete programs/professors have developed their own tools for assessment that may not be useful in other programs. The National Service Learning Clearinghouse has developed a guide for designing such program specific evaluation tools. ${ }^{\text {xxii }}$ This guide, designed to assist educators in designing methodologically sound assessment tools, helps to identify whether and what type of evaluation is necessary, as well as how to create and tailor assessments to any given program.

The difficulty of this type of assessment is that it is possible that SL may operate differently in varied collegiate environments. That is, the results from a private university in the Midwest $^{\text {xxxiii }}$ may not be the same as those experienced by undergraduates at our university and who are working with the local population. Also, the types of SL assignments may be different designing new logistics for a food bank requires a different type of preparation and assessment than teaching and mentoring schoolchildren.

While assessment in service learning presents its own unique challenges, successful assessments conducted by outside researchers have been done using both qualitative (focus groups, interviews, artifact analysis), quantitative (surveys, analysis of raw data on retention/GPA, etc.), and mixed method assessment tools (the results of which have been discussed above). However, while the NSLC guide suggests that research be either comparative across subjects or time, many studies still collect and analyze data in a post-hoc manner, using journals or surveys that were collected at one point in time. ${ }^{\mathrm{xxxiv}, \mathrm{xxxv}}$ 


\section{Service Learning in Engineering}

Although SL courses and research on its efficacy have proliferated in American universities over the past few decades in multiple fields, SL in engineering began formally in the 1990s. ${ }^{\text {xxxvi,xxxvii }}$ Previous research has been positive about the effects of SL on engineering undergraduates in the areas of content knowledge and thinking skills: ${ }^{\text {xxviii,xxxix }}$ It aids students in developing reflective judgment and critical thinking skills, ${ }^{\mathrm{xl}}$ enhancing content knowledge and communication skills, ${ }^{\text {xli }}$ and increasing their enjoyment of the discipline. ${ }^{\text {xlii }}$ Additionally, using pre- and post-tests in a program similarly organized to our own (undergraduates engaging with schoolchildren for about 15 hours), Steward ${ }^{\text {xliii }}$ found that SL increased undergraduates' sense of self-efficacy. This was measured through their desire and confidence to engage in community service in the future.

SL assessment in engineering - like SL assessment in other fields - has many challenges. One notable metric used to assess SL in this discipline, specifically, is the National Engineering Students' Learning Outcomes Survey (NESLOS), ${ }^{\text {xliv,xlv }}$ which uses pre-established learning outcomes from the Accreditation Board of Engineering and Technology (ABET) and the National Academy of Engineering Center for the Advancement of Scholarship on Engineering Education (NAE CASEE) to ask students to compare their SL experience with their coursework on several key elements, such as the ability to work in a team, the acquisition and application of STEM knowledge, and the ability to persevere. A shortened version of NESLOS was recently tested through an online survey of 261 students who had been enrolled in SL at different universities to validate the metric. Carberry, Lee and Swan ${ }^{\text {xlvi }}$ determined that engineering students who had completed SL attributed $45 \%$ and $62 \%$ of what they've learned about technical skills and professional skills (respectively) to SL, with female students skewing above average in both.

\section{Importance of Student Self-Perception}

Theory and research have long established that student self-perceptions are important and highly correlated with student performance and retention. ${ }^{\text {xlvii,xlviii }}$ Social-cognitive theory (c.f. Bandura) asserts that a person's perception of self-efficacy has direct effects on his or her performance of a variety of tasks. Specifically, Bandura xlix asserts that "self-referent thought ... mediates the relationship between knowledge and action... self-referent misgivings create stress and impair performance by diverting attention from how best to proceed with the undertaking to concerns over failings and mishaps. In contrast, persons who have a strong sense of efficacy deploy their attention and effort to the demands of the situation and are spurred to greater effort by obstacles." Subsequent research applies perceived self-efficacy directly to student learning. For example, Zimmerman ${ }^{1}$ discusses "self-regulated learners," defined as students who rely heavily on their own self-perception who "self-evaluate at various points during the process of [skill/knowledge] acquisition." He asserts that students' use of self-regulated learning strategies plays an important role in academic achievement. More to the point, Schunk's ${ }^{\text {li }}$ study confirms that "Ability was positively related to skillful performance, but regardless of ability level, students with higher efficacy solved more problems correctly and chose to rework more that they missed...Self-efficacy for learning also relates positively to posttest self-efficacy and skill." More recently, Vogt et al. ${ }^{\text {lii }}$ has used an instrument called Student Assessment of Learning Gains (SALGains), which measures academic growth in business students, and with the help of this metric reported "a high level of proficiency" in the students studied. 
Additionally, the examination of student self-perception is well established in SL literature. Scholars have examined students' perceptions of the effects and importance of community service ${ }^{\text {liii,liv,lv }}$ as well as their own perceptions about their learning experience ${ }^{\text {lvi }}$ and their attitudes and values. ${ }^{\text {lvii }}$ Overall, from this research, we can conclude that measuring studentperception of skill acquired as a result of SL, as well as their perception of the importance of given skills, is a valuable and valid indicator of their future performance. Therefore, students' perceptions of their growth on certain skills are helpful in aiding their later achievement and persistence in boosting both technical and professional skills. Specifically regarding engineering freshmen students, Besterfield-Sacre, Atman, and Shuman ${ }^{\text {lviii }}$ found that measuring changes in perceptions about educational experience as well as attitudes towards engineering matter a great deal for attrition in engineering. Thus, being able to measure any changes in freshmen students' perceptions for skill improvement while in service learning in engineering matters for their persistence in the program. The present study will both assess the discipline specific skills that students believe are important, and their perception of how adept they are in those skills.

\section{METHODS}

\section{Data Sources and Collection}

Data for this paper were collected from undergraduates through three main methods - two written and one oral. All of the sources for these data were also methods of assessment for different aspects of the efficacy of SL, thus they were not only sources of content data, but also methods that we were analyzing for completeness and ability to gather data about SL assessment. Overall, there were 96 students in this sample who had completed this course in the past three years. We have writing assignments from 89 of them, and 6 chose to participate in in-depth focus groups. Of that 6 , all were male, four were white, one was black, and one was Hispanic. All were between the ages of 19 and 22, all participated outside of class time (thus likely selfselecting for students who care about service learning), and 5 of the 6 were currently enrolled in the course. The $6^{\text {th }}$ was enrolled in the previous semester it was offered.

The first written method was a short writing assignment that asked undergraduates to identify the main skills that they believe engineers need in their professional lives, and then rate themselves on those skills. Then, at the end of the semester, students were asked to consider the list of skills they made at the beginning of the semester and re-evaluate themselves based on their SL experience. To determine what skills undergraduates believe engineers need in their professional lives, we deliberately did not provide one uniform list of skills on which the undergraduates could assess themselves. While this did complicate data analysis, we believe that this method of assessment was more valid and accurate, in that open-ended questions allowed for the greatest freedom of answers, as well as forced the undergraduates to think critically and predict what skills they will need (and might need to start developing now, in a SL course) as professionals.

The second written method was a journal assignment. Students were asked to write down what time and days they had entered the classroom, as well as what they had done with schoolchildren that day. Students were also asked to briefly reflect on what was effective while mentoring the children. We were able to link these two data sources by student identifier (i.e., we were able to read Student 1's two self-assessments with his/her journal to see if there was change over time or other patterns in the data). 
The oral method of data collection was through focus groups run by one of the co-authors who is not the course instructor. Before beginning, it was explained to the students that their professor would not hear their thoughts until after grades were in, and they would not be individually identifiable. The interview schedule was semi-structured, although only to the extent that the order of questions was changed to fit the conversation and clarifying questions were added as needed. The focus groups were recorded, and then transcribed. These three sources of data were entered into a qualitative data analysis software program, and then were coded for thematic commonalities.

\section{Analysis Methods}

To analyze the skills assignments at the beginnings (Time 1) and ends (Time 2) of the semesters under study, we first compiled all the skills that the undergraduates had written into a spreadsheet to determine how often certain skills were mentioned, and whether any groups could be made. For example, mentions of "communication" were grouped with "communication skills," "communication/listening," "conversation," and "good communication skills." See Table 1 for the groupings. Overall, 473 of 767 responses (61.59\% of responses) were grouped into 12 categories. We stopped at 12 because of the sharp decrease in number of mentions between the $12^{\text {th }}$ category ("Attention to Detail" with 22 mentions) and the next category (not mentioned in this paper, with 10 mentions).

We were conservative in our grouping, and on the two occasions where we felt that an undergraduate had written something that could fit in two categories ("math and technical skills" and "computer/technical literacy"), we placed it in the first category mentioned (i.e., "Math and Science" and "Computer," respectively). Since these were only two mentions out of 473, we do not believe this materially changed the results. To check this assumption, we re-ran the statistical tests with them deleted. Omitting these data only changed the means and standard deviations in a minor manner and did not change the overall findings of statistical significance, thus we included them. 


\section{TABLE 1 SKILLS DESCRIPTORS}

\begin{tabular}{|c|c|c|c|c|c|c|}
\hline \multicolumn{7}{|c|}{$\begin{array}{l}\text { Student Responses } \\
\text { (grouped into Skill Groups) }\end{array}$} \\
\hline Communication & $\begin{array}{l}\text { Communication } \\
\text { skills }\end{array}$ & $\begin{array}{l}\text { Communication/ } \\
\text { listening }\end{array}$ & Communicator & Conversation & $\begin{array}{l}\text { Good } \\
\text { communication } \\
\text { skills }\end{array}$ & Listening skills \\
\hline Team player & $\begin{array}{l}\text { Ability to work } \\
\text { with others }\end{array}$ & Good with others & Group cooperation & Group work & Interpersonal & People friendly \\
\hline Math & Math/ Physics & Math \& Science & $\begin{array}{c}\text { Math and Technical } \\
\text { Skills }\end{array}$ & Mathematics & Physics & \\
\hline Creative thinking & Creativity & Creative \& inventive & Creative answers & Creativeness & Inventive & $\begin{array}{l}\text { Think outside the } \\
\text { box }\end{array}$ \\
\hline Problem Solver & Problem Solving & $\begin{array}{l}\text { Able to spot and fix } \\
\text { bugs }\end{array}$ & Failure analysis & & & \\
\hline Leadership & Leadership skills & $\begin{array}{l}\text { Leadership/ } \\
\text { management }\end{array}$ & Manage people & Management & $\begin{array}{c}\text { Project } \\
\text { management }\end{array}$ & \\
\hline Computer & $\begin{array}{l}\text { Computer } \\
\text { knowledge }\end{array}$ & Computer literacy & $\begin{array}{l}\text { Computer modeling } \\
\text { skills }\end{array}$ & $\begin{array}{l}\text { Computer } \\
\text { /technical } \\
\text { literacy }\end{array}$ & $\begin{array}{l}\text { Computer } \\
\text { /software }\end{array}$ & $\begin{array}{l}\text { Computer/ } \\
\text { technology } \\
\text { friendly }\end{array}$ \\
\hline Technical & $\begin{array}{l}\text { Technical } \\
\text { Knowledge }\end{array}$ & Technical skills & Technology & Technological & Technology skills & $\begin{array}{l}\text { Understanding of } \\
\text { tools }\end{array}$ \\
\hline Time management & Timeliness & Punctual & Punctuality & & & \\
\hline Analytical Skills & Analytical & Analyze problems & & & & \\
\hline Orderliness & $\begin{array}{c}\text { Organizational } \\
\text { skills }\end{array}$ & Organization & Organized & $\begin{array}{l}\text { Planning/ } \\
\text { organizing }\end{array}$ & & \\
\hline Attention to detail & Being thorough & Detail oriented & Precise & $\begin{array}{l}\text { Precision and } \\
\text { accuracy }\end{array}$ & $\begin{array}{c}\text { Shows attention to } \\
\text { detail }\end{array}$ & \\
\hline
\end{tabular}

To test if there were any statistically significant changes between Time 1 and Time 2, a paired samples t-test was run on the students' numerical assessments on each skill mentioned, within each category. For example, as we can see in Table 1, 66 students mentioned teamwork at Time 1, and rated themselves on a 1-5 scale. Thus, these students were compared at Time 1 and 2 to determine if the mean changed significantly. If a rating was missing at Time 1 or 2 , the student was omitted from the analysis - in the example of teamwork above, this left us with 51 usable data pairs (where we had a rating from the same student at Time 1 and 2) for analysis. 
From this information, we were able to question undergraduates during the focus groups in a more in-depth manner about those particular practices, and how they think that they should be assessed. We built our recommendations for how to assess practices in SL from the words and experiences of the students themselves (mostly based on the skills assessment exercise and journals, but checked and informed by the focus groups), thus creating a more authentically student-based assessment tool.

\section{ANALYSIS \& DisCUSSION}

\section{Student-Developed Skills - Quantitative Changes}

As mentioned above, we compiled 767 responses to the original question of what skills students believe are important for engineers to have. These responses include those which were duplicated by multiple students in their lists of important skills. Once compiled and analyzed (see Table 1), 12 groups containing 473 responses were created based on word synonyms. Within each group, a paired-samples t-test was conducted to determine if students perceived that they had grown (over the course of the semester) in that attribute that they had originally listed.

The question originally posed was, "Identify the main skills you think engineers need in their professional lives and rate yourself on those skills." This question was deliberately broad as to determine what students thought might be important skills to develop now, and also deliberately not focused solely on the skills they thought might be affected by service-learning. This is because we hypothesized that, since this was the students' first experience with SL, they might not realize how it could affect them. This hypothesis was confirmed by the students in the focus groups as well as the writing assignments, which almost universally stated some form of surprise at how this service-learning experience had affected them. In future research (which is discussed more in the "Future Research" section below), we plan to use this metric simultaneously in the regular and SL sections of this course to determine the perceived efficacy of SL on these skills. However, that is currently beyond the scope of this paper, which focuses on developing a metric that uses the students' own perceptions and words.

TABLE 2

STATISTICAL RESUlts

\begin{tabular}{|l|l|l|l|}
\hline Skill & Time 1 Mean (SD, SE) & Time 2 Mean $($ SD, SE) & Increase or Decrease \\
\hline Communication & $3.324(.97, .16)$ & $3.757(.9, .15)$ & Increase by $.433^{* *}$ \\
\hline Teamwork & $3.833(1.06, .15)$ & $4.222(.81, .11)$ & Increase by $.389^{* * *}$ \\
\hline Math and Science & $3.302(.72, .12)$ & $3.592(.69, .11)$ & Increase by $.29^{* * *}$ \\
\hline Creativity & $3.574(1.11, .19)$ & $3.912(.94, .16)$ & Increase by $.338^{* * *}$ \\
\hline Problem Solving & $3.554(.98, .18)$ & $4.003(.77, .14)$ & Increase by $.449^{* * *}$ \\
\hline Leadership & $3.5(1.24, .29)$ & $4.028(1.05, .25)$ & Increase by $.528^{* * *}$ \\
\hline Computer & $3.571(1.06, .23)$ & $3.762(.9, .2)$ & Increase by .191 \\
\hline Technical & $3.25(1.01, .27)$ & $3.535(.89, .24)$ & Increase by .285 \\
\hline Time Management & $2.865(.89, .25)$ & $3.5(.54, .15)$ & Increase by $.635^{* * *}$ \\
\hline Analytical & $3.867(.81, .21)$ & $3.967(.64, .17)$ & Increase by .1 \\
\hline Organizational & $3.25(1.05, .3)$ & $3.48(.97, .28)$ & Increase by .229 \\
\hline Attention to Detail & $4.038(.72, .2)$ & $4.269(.63, .18)$ & Increase by .231 \\
\hline
\end{tabular}

$* \mathrm{p} \leq .1$

$* * p \leq .05$

$* * * \mathrm{p} \leq .01$ 
In Table 2, we can see that students reported a perceived increase in all 12 categories (on a 1-5 scale, with 5 being the highest). Seven of the 12 categories' increase was statistically significant.

a) For Communication skills, there was a significant difference in the scores between Time $1(\mathrm{M}=3.324, \mathrm{SD}=.97)$ and Time $2(\mathrm{M}=3.76, \mathrm{SD}=.9) ; \mathrm{t}(36), \mathrm{p} \leq .05$. This means that students perceived an average growth of .433 in communication skills during the course of this service learning course.

b) For Teamwork skills, there was a significant difference in the scores between Time 1 $(\mathrm{M}=3.833, \mathrm{SD}=1.06)$ and Time $2(\mathrm{M}=4.222, \mathrm{SD}=.81) ; \mathrm{t}(50), \mathrm{p} \leq .01$. This means that students perceived an average growth of .389 in teamwork skills during the course of this service learning course.

c) For Math and Science skills, there was a statistically significant increase of .29 between Time $1(\mathrm{M}=3.302, \mathrm{SD}=.72)$ and Time $2(\mathrm{M}=3.592, \mathrm{SD}=.69) ; \mathrm{t}(37), \mathrm{p} \leq .01$.

d) For Creativity, students reported a statistically significant increase of .338 between Time $1(\mathrm{M}=3.574, \mathrm{SD}=1.11)$ and Time $2(\mathrm{M}=3.912, \mathrm{SD}=.94) ; \mathrm{t}(33), \mathrm{p} \leq .01$.

e) For Problem Solving skills, students reported a statistically significant increase of .449 between Time $1(\mathrm{M}=3.554, \mathrm{SD}=.98)$ and Time $2(\mathrm{M}=4.003, \mathrm{SD}=.77) ; \mathrm{t}(27), \mathrm{p} \leq .01$.

f) In Leadership skills, students reported a statistically significant increase of .528 between Time $1(\mathrm{M}=3.5, \mathrm{SD}=1.24)$ and Time $2(\mathrm{M}=4.028, \mathrm{SD}=1.05) ; \mathrm{t}(17), \mathrm{p} \leq .01$.

g) For Computer skills, students reported an increase of .191 between Time $1(\mathrm{M}=3.571$, $\mathrm{SD}=1.06)$ and Time $2(\mathrm{M}=3.762, \mathrm{SD}=.9)$, but it was not statistically significant.

h) Technical skills was also an area in which students reported an increase (of .285), but it also was not statistically significant (Time $1 \mathrm{M}=3.25, \mathrm{SD}=1.01$; Time $2 \mathrm{M}=3.535$, $\mathrm{SD}=.89$ ).

i) However, Time Management, the skill with the lowest mean at Time $1(2.865$, $\mathrm{SD}=.89$ ), had the highest reported increase of all skills mentioned at .635. This was statistically significant (Time $2 \mathrm{M}=3.5, \mathrm{SD}=.54) ; \mathrm{t}(12), \mathrm{p} \leq .01$.

None of the last three skills mentioned by the students (Analytical skills, Organizational skills, and Attention to Detail) were statistically significant.

\section{Student Developed Skills - Qualitative Data}

Using the journal assignments and the focus groups, we were able to enlarge upon the quantitative data listed above. Some of largest statistically significant increases came from skills that the students pointed to in their journals and in the focus groups as ones that had been particularly important in their SL project (in order of perceived increase): Time Management, Leadership, Problem Solving, Communication, Teamwork, and Creativity. The students report that the seventh statistically significant increase, Math and Science Skills, came from both the SL project in the course and the academic content of the course itself. Below, we explain how and why students reported utilizing and honing these skills during service learning. 
Students who reported positive changes in their time management skills explained that the pressure to succeed made increased work efficiency more important. This pressure came from the additional amount of work they had to do to be successful during their semesters they participated in the LEGO robotics competition. One student noted that he increased his own work efficiency and time management skills because when the students got frustrated, "it was necessary for the mentors to keep a cool head and encourage the students to keep working on it!" Interestingly, some of the students reported decreasing their assessment of their own time management skills during the service learning, and as such, one of them recognized that he had more room for improvement than he previously realized. The other two students who both reported a decrease on their journal assignments said that after watching the children try to achieve success, they realized that those with the best time management skills were most likely to be successful. As a result, they noted that increased importance of this skill showed them that they, too, have room for improvement.

Students reported in both focus groups and their journal assignments that their leadership skills were developed out of necessity. They noted that when they had several students in a room without a teacher, they were required to be leaders in order to maintain order and productivity. Some students recognized their position as a mentor to young students: "the kids at my school looked up to me as an idol and when I suggested they do something with their robots they did it, and I started to see myself as not only a mentor to them but as a leader."

Almost universally in both the journal assignments and focus groups (with the exception of one student), students attributed their increased problem solving abilities to the K-12 studentbased technical problem solving that this course required of them. Many students mentioned that working with the schoolchildren presented unique challenges and chances to improve their own skills. For example, one student explained that his students' ingenuity surprised him: "there is something about children that gives them the ability to see problems in very unique ways. I had to sit back and watch their methods before I could believe they would work." Finally, many students explained that teaching the children how to solve their own problems, instead of doing it for them, served to increase their own understanding of problem solving skills.

Students who reported increased communication skills pointed to the necessity of communicating well with children and their teachers, as well as their own peers, in order to effectively and efficiently do their work. Students noted that while it would have been easier to do the tasks for the children, they stretched their communication abilities by instead explaining to the children how they should do something and why they should do it in a particular way. Students explained the importance of being able to communicate ideas to children and other nonengineers in non-technical ways that are simple to understand: "... and it's not just the kids. I was talking to so many parents and teachers who come in and like, 'what are they doing?' and it was really good for my communication skills." During the focus group, two of the students who reported negative change in this area said that they realized that they need to work on their communication skills when they had difficulty doing just this.

Regarding teamwork skills, students mentioned two types of groups that they needed to manage and interact with: their peer groups (the other students in the service learning class) and the K-12 student groups (who they were mentoring). They reported in journal assignments that the first type of group actually elicited more frustration because they expected their peers to interact with the children in the same manner or have similar work ethics and plans. In the focus groups, students mentioned that coming to a consensus with their peers was difficult, but possible. With the student groups, the undergraduates felt that they needed to mentor the 
students in how to best work as a team, which they considered a different dynamic than the teamwork skills used with their own peer groups. Even though the K-12 students were younger and less mature, undergraduates actually reported that mentoring those skills in the younger students helped them to realize how to improve their own skills: "the biggest challenge was my partner...who took a very hands off approach...but I learned to mimic all the teachers I've had throughout my life, ...so I would have to intervene and they could learn to figure out their own problems. I was able to model [teamwork] for them."

Creativity was a concept that many students mentioned as another dual level skill: something they needed to encourage in their K-12 students and something they needed to utilize themselves while working with said students. As one student put it during a focus group, "of course, that was a definite necessity, because the kids wanted to use duct tape on everything. Their creativity level was like a 1 or a 2." This student said that he had to invent creative ways to make the kids be more creative in their approaches to the LEGO kits.

Overall, the students who reported increased technical skills and/or math and science skills attributed this increase directly to the applied technical, math and science skills they employed while building and programming their robots. Students reported increased knowledge of programs they employed, such as MATLAB and the LEGO NXT software. Additionally, students reported that increased math knowledge came from explaining mathematical concepts to the children, so they could do their work in the most efficient way possible. Overall, students reported greater understanding of the importance of math skills.

\section{Students' Recommendations for Assessment}

In previous years of this course, we have attempted to assess the effects of SL on students through written means: the journal and skills assignments described in the methods section above. However, this year, we decided to add focus groups run by one of the authors who was not an instructor of this course. At these groups and in conversations during the competitions, students also described the effects of the different assessments on their learning process. Most felt that the written assignments were helpful, but were incomplete in describing how SL had affected them and did not provide enough guidance at the beginning of the semester as to how they should be assessing themselves. Students in the focus groups and during interpersonal contact during the competitions reported liking the chance to reflect on their experience and express their thoughts verbally to the researchers.

Overall, there were two key recommendations that the students made regarding how they would like to be assessed in SL. While some of their thoughts were tied into how they would like to be graded, many of them also reported wanting other, more informal and subjective assessment to aid them in later professional growth. The below two recommendations were formed based on what the students reported as being helpful in assessing their own growth:

1) Assessment should be authentic, regularly done, and written

Students overwhelmingly liked the journal assignment, in which they were asked to quickly write down the date of their service, what they accomplished, and what their goals were for the future. The authenticity (that is, how well it reflects the lived experiences of the respondents) and utility of this self-assessment allowed students to have tangible proof of their work, as well as aid the instructor in determining their progress. Students also suggested that this journal be an assignment that is emailed to the instructor on a biweekly basis in order to head off any issues that the student or his/her group mates may be having. This would also provide a 
check on group "free ridership," in which one member of the team does most of the work. As one student put it, journals are really good "to see who's more involved, maybe, and to make it personal...to really get a feel for who's doing this, and who's not." Additionally, students pointed out that, if the instructor saw that students were having common problems, the instructor could be responsive and devote a few minutes of class time to brainstorming solutions for the whole class. This also adds a way for students to reflect on events as they happen (formative reflection), and the ability to be more accurate and retrospective in their end-of-semester summative re-assessment.

2) Assessment should encompass multiple skill types and be standardized

In speaking with students at the end of the semester, most wished that they had "known then what I know now" about the skills on which SL focuses. In their initial skills assignment, at the beginning of the semester, they felt like they had been ignorant as to the skills that engineers might need and those that can be improved through SL. Many wished that they had written about and ranked skills such as problem solving and communication skills higher. From these recommendations, we developed the Engineering Skills Assessment (ESA) seen in Figure 1 (Appendix). This is a standardized assessment tool that came out of the students' thoughts about what skills were necessary and what they should be assessed on during this class, but is a metric that can be used at both the beginning and end of the semester, thus providing a standard on which to measure growth. We suggest that instructors assign this metric in the first week of class, and then at the end, but also include a brief written reflection for students at the end. We also suggest that instructors use the thematic grouping of cognitive skills, other-oriented skills, and content knowledge skills that we developed above, in order to determine if there are particular areas that may require more focus during instructional time. As many students told us, "looking back, I'd want to be able to measure myself on those things in advance and show growth over time to show me where I need to improve." At the end of the semester, we suggest that instructors add a fourth column that allows for written student reflection, so as to allow students to process their growth over the semester.

\section{LIMITATIONS}

The purpose of this paper was to identify the important skills that students reported as having gained from this SL course, as well as their thoughts about assessment in SL. Then, to use those thoughts to establish an authentic and student-originated standardized assessment tool that could be given to students at the beginning and end of the semester to track student perception of growth. Thus, one limitation of this assessment tool is that it is based solely on student perceptions. Additionally, it may be that students realize during the course of SL that their initial self-assessments were too high, therefore causing negative growth on paper when the pre- and post-test are compared, but in reality showing that they have grown in understanding their own skills.

The 96 students who took part in this assessment creation are a small sample size, although they provided nuanced data for qualitative analysis. They are also a self-selected population - even if they were initially unaware that this section was SL, they had the chance to withdraw from it. Also, students had to decide to participate in the focus groups, thus biasing that data source. In the future, we plan to test this metric on students in both the regular and SL 
sections of this course to determine if there are different growth curves by course type in students' perceptions of their skills in certain areas hypothesized to be strengthened by SL.

\section{CONCLUSIONS}

This study used data provided by students enrolled in a SL course to determine the skills that they thought would be of help to them as engineers which they also said were developed through their experience in SL. Then, the students themselves reflected on different assessment strategies and metrics to determine that they wanted assessments that were based in their own experiences, as well as assessments that could be used to inform their practice throughout the semester. From their words, we first recommend a journaling assignment that can be regularly reviewed by instructors and discussed in class. Secondly, we have developed a new assessment metric that is naturalistic and authentic, as well as capable of showing growth over time. This new assessment metric, ESA, should be given at the beginning and end of the semester to allow students to measure their own growth and be invested in their own development as professional engineers.

\section{Areas OF Future Research}

Areas of future research that are beyond the scope of this study include testing the validity of the metric developed by using it to assess students who take different sections of the same course, when one section is SL, and the other is not. Data should also be gathered over a more longitudinal study to rule out the possibility that variance is due to an artifact of one particular year or section. Further research would also benefit from comparing similar types of SL programs at varying universities. Finally, the examination of perceived growth would be further validated when compared to post-collegiate academic or professional success.

\section{ACKNOWLEDGEMENTS}

This work was partly funded through the Texas Tech University's Whitacre College of Engineering Butler Distinguished Educator Fellowship. 


\section{APPENDIX}

\section{Figure 1 - Engineering Skills Assessment}

Rank each of the skills listed below in order of how important you believe they are for an engineer to have ( 1 being least important, and 5 being most important). Then, on a scale of 1-5, how well developed you are in that skill ( 1 being not developed at all, 5 being fully developed $)^{1}$.

\begin{tabular}{|c|c|c|}
\hline & $\begin{array}{c}\text { Importance for } \\
\text { Engineering }\end{array}$ & $\begin{array}{c}\text { Self-Development } \\
\text { Score }\end{array}$ \\
\hline Communication Skills, Including Listening Skills & & \\
\hline Ability to Work Effectively on a Team/Group & & \\
\hline $\begin{array}{c}\text { Math and Science Skills and Knowledge } \\
\text { (not including computer skills) }\end{array}$ & & \\
\hline Ability to Be Creative & & \\
\hline Problem Solving Skills & & \\
\hline Leadership and Management Skills & & \\
\hline $\begin{array}{c}\text { Computer Skills } \\
\text { (including programming and modeling) }\end{array}$ & & \\
\hline Technical Skills and Knowledge & & \\
\hline Time Management Skills & & \\
\hline (including punctuality) & & \\
\hline Analytical Skills & & \\
\hline Attention to Detail & & \\
\hline Orderliness and Organizational Skills & & \\
\hline
\end{tabular}

\footnotetext{
${ }^{1}$ At the end of the semester, a fourth column should be added to ask why any changes took place, in order to determine which elements of SL were helpful for that student and aid in self-reflection.
} 
International Journal for Service Learning in Engineering Special Edition, pp. 29-47, Fall 2013

ISSN 1555-9033

\section{REFERENCES}

${ }^{i}$ Edmund Tsang et al., "A Report on Service-Learning and Engineering Design: Service-Learning's Effect on Students Learning Engineering Design in 'Introduction to Mechanical Engineering," International Journal of Engineering Education 17, (2001), 30-39.

ii Jeremy Cohen and Dennis Kinsey, “'Doing Good' and Scholarship: A Service Learning Study," Journalism Educator 48, no. 4 (1994), 4-14.

iii John Duffy, Linda Barrington, William Moeller, Carol Barry, David Kazmer, Cheryl West, and Vivian Crespo, "Service-Learning Projects in Core Undergraduate Engineering Courses," International Journal for Service Learning in Engineering 3, no. 2 (2008), 82-41.

${ }^{\text {iv }}$ William Oakes, John Duffy, Thomas Jacobius, Panos Linos, Susan Lord, William Schultz, Amy Smith, "ServiceLearning in Engineering" Paper presented at the $32^{\text {nd }}$ conference of the ASEE/ISEE Frontiers in Education, Boston, MA, 2002.

${ }^{v}$ Olga Pierrakos, Maura Borrego, and Jenny Lo, "Assessing Learning Outcomes of Senior Mechanical Engineers in a Capstone Design Experience," Paper presented at the proceedings of the American Society for Engineering Education Annual Conference \& Exposition, Honolulu, HI, 2007.

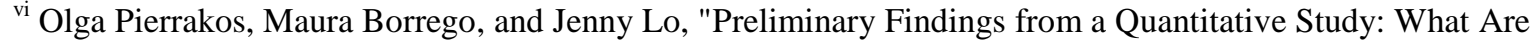
Students Learning During Cooperative Education Experiences?" Paper presented at the proceedings of the American Society for Engineering Education Annual Conference \& Exposition, Pittsburgh, PA, 2008

vii Texas Tech University Course Catalog

viii “2012-2013 Criteria for Accrediting Engineering Programs,” accessed November 10, 2013, http://www.abet.org/uploadedFiles/Accreditation/Accreditation_Process/Accreditation_Documents/Current/eaccriteria-2012-2013.pdf

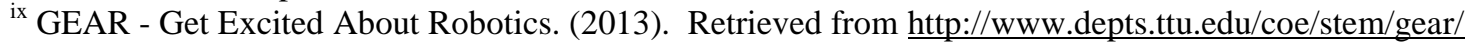

${ }^{\mathrm{x}}$ Introduction to Engineering (ENGR 1315) Syllabus.

http://appserv.itts.ttu.edu/PACI/Pages/Courses/CourseSyllabus.aspx?6964=523030353337393134\&6370726566697 $\underline{8=454 \mathrm{E} 4752 \& 636 \mathrm{E} 756 \mathrm{D}=31333135 \& 73656374=533033 \& 7465726 \mathrm{D}=537072696 \mathrm{E} 6720545455 \& 79656172=32303}$

$\underline{133}$

xixi Tanja Karp. "Teaching a Service Learning Introductory Engineering Course - Lessons Learned and Improvements Made." Paper presented at the 41st conference of the IEEE/ASEE Frontiers in Education Conference, Rapid City, SD, 2011.

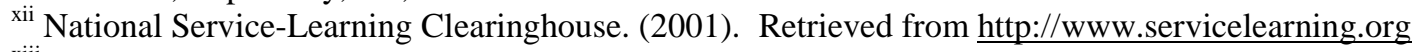

xiii John Dewey, The School and Society (Chicago: The University of Chicago Press, 1915) 44.

${ }^{x i v}$ Karl A. Smith et al. "Pedagogies of Engagement: Classroom-Based Practices" Journal of Engineering Education 94, no. 1 (2005), 87-101.

${ }^{\mathrm{xv}}$ Howard S. Barrows, "Problem-Based Learning in Medicine and Beyond: A Brief Overview" in Bringing Problem-Based Learning to Higher Education: Theory and Practice ed. LuAnn Wilkerson and Wim H. Gijselaers, (San Francisco: Josey-Bass, 1996), 5.

${ }^{x v i}$ Howard Barrows and Robyn Tamblyn, Problem Based Learning: An Approach to Medical Education (New York: Springer, 1980).

xvii Barrows, Problem Based Learning, 12.

xviii Robert G. Bringle, Mindy A Phillips, and Michael Hudson, The Measure of Service Learning: Research Scales to Assess Student Experiences (Washington, D.C.: American Psychological Association, 2004)

${ }^{x i x}$ Bringle Phillips and Hudson, Measure of Service Learning, 2004.

${ }^{\mathrm{xx}}$ Eyler, J. et al. At a glance: What we know about the effects of service-learning on college students, faculty, institutions and communities, 1993-2000: Third Edition. (Nashville, TN: Vanderbilt University, 2001).

${ }^{\mathrm{xxi}}$ A. W. Astin and L.J. Sax, "How Undergraduates are Affected by Service Participation," Journal of College Student Development, 39 no. 3 (1998), 251-263.

xxii Janet Eyler and Dwight E. Giles Jr., "Where's the Learning in Service-Learning?" (San Francisco: Jossey-Bass, 1999).

xxiii Giles and Braxton 1997

${ }^{x x i v}$ L.M. Fenzel and T.P. Leary "Evaluating Outcomes of Service-Learning Courses at a Parochial College," Paper presented at the Annual Meeting of the American Educational Research Association, Chicago, IL, 1997. 
${ }^{x x v}$ L.J. Vogelgsang and A.W. Astin, "Comparing the Effects of Service-Learning and Community Service," Michigan Journal of Community Service Learning, 7 (2000), 25-34.

${ }^{x x v i}$ M.J. Gray et al., "Coupling Service and Learning in Higher Education: The Final Report of the Evaluation of the Learn and Serve America, Higher Education Program," The RAND Corporation (1998).

xxvii Alexander Astin and L.J. Sax, "How Undergraduates are Affected by Service Participation," Journal of College Student Development 39, no. 3 (1998), 251-263.

xxviii C. Keen and J. Keen "Bonner Student Impact Survey,” Bonner Foundation (1998).

${ }^{x x i x}$ Astin and Sax, Service Participation, 1998.

${ }^{x x x}$ M.J. Gray et al., Coupling Service and Learning, 1998.

${ }^{\mathrm{x} x \mathrm{i}}$ Eyler and Giles, Where's the Learning, 1999.

${ }^{x x x i i}$ National Service-Learning Clearinghouse. (2001). The educator's guide to service-learning program evaluation. Retrieved from http://www.servicelearning.org/filemanager/download/37/EvaluationToolkit.pdf

xxxiii Panagiotis Linos, Stephanie Herman, and Julie Lally, "A Service-Learning Program for Computer Science and Software Engineering." ITiCSE 35, no. 3 (2003), 30-4.

${ }_{\text {xxxiv }}$ Blackwell, A. P. "Students' Perceptions of Service Learning Participation in the College of

Health and Human Sciences at The University of Southern Mississippi" (PhD diss., The University of Mississippi, 1996).

${ }^{x x x v}$ Berthiaume, J. L., "Community Service Learning Perceptions of Selected Students Attending a University in the Southeast Region of the United States" (PhD diss., University of Southern Mississippi, 1999).

${ }^{x x x v i}$ Adam Carberry, Hee-Sun Lee, and Christopher Swan, "Student Perceptions of Engineering Service Experiences as a Source of Learning Technical and Professional Skills," International Journal for Service Learning in Engineering 8, no. 1 (2013), 1-17.

xxxvii Edmund Tsang, Projects That Matter: Concepts and Models for Service Learning in Engineering (Sterling, VA: Stylus Publishing, 2000)

xxxviii Alexander W. Astin et al., "How Service Learning Affects Students," Higher Education Research Institute. University of California: Los Angeles, 2000.

${ }_{\text {xxxix }}$ Leah H. Jamieson, William C. Oakes, and Edward J. Coyle, "EPICS: Documenting Service-Learning to Meet EC 2000," Paper presented at the $32^{\text {nd }}$ conference of the ASEE/ISEE Frontiers in Education, Boston, MA, 2000.

${ }^{x 1}$ Lynne Slivovsky, Frank DeRego. Leah Jamieson and William Oakes. "Developing the Reflection Component in the EPICS Model of Engineering Service Learning." Paper Presented at the $33^{\text {rd }}$ conference of the ASEE/IEEE Frontiers in Education, Boulder, Co, 2003.

xli Tsang "Report on Service-Learning" 2001.

xlii Oakes et al., "Service-Learning in Engineering," 2002.

xliii Trae Steward, "Community Service Self-Efficacy and First-Year Undergraduate Honors Service-Learning." in Scholarship for Sustaining Service Learning and Civic Engagement. (Information Age Publishing, Inc., 2008), 2953.

xliv Perriakos, "Assessing Learning Outcomes," 2007

xlv Perriakos, "What Are Students Learning," 2008

xlvi Carberry, "Student Perceptions," 2013.

xlvii Allan Wigfield and Jacquelynne Eccles, "Expectancy-Value Theory of Achievement Motivation." Contemporary Educational Psychology. 25, no. 1 (2000), 68-81.

xlviii Robert Vallerand, Michelle Fortier, and Frederic Guay. "Self-Determination and Persistence in a Real-Life Setting: Toward a Motivational Model of a High School Dropout." Journal of Personality and Social Psychology, 72, no. 5 (1997), 1161-1176.

xlix Albert Bandura, "Self-efficacy Mechanism in Human Agency," American Psychologist 32, no. 2 (1982), 122147.

${ }^{1}$ Barry Zimmerman, "Self-Regulated Learning and Academic Achievement: An Overview," Educational Psychologist 25, no. 1 (1990): 3-17.

${ }^{\text {li }}$ D.H. Schunk "Self-efficacy and Achievement Behaviors," Educational Psychology Review, 1 (1989): 173-208.

lii Gayle Vogt, Catherine Atwong, and Jean Fuller. "Student Assessment of Learning Gains (SALGains): An Online Instrument," Business Communication Quarterly, 68 no. 1 (2005), 36-43.

${ }^{\text {liii }}$ Miller, J. "The Impact of Service-Learning Experiences on Students' Sense of Power," Michigan

Journal of Community Service Learning, 4 (1997), 16-21.

${ }^{\text {liv }}$ R. Parker-Gwin and J. B. Mabry, "Student Attitudes Toward Service-Learning: Implications for implementation," Journal of Management Education, 23 no. 5 (1998), 276-291. 
${ }^{\text {Iv }}$ Dwight E. Giles Jr. and Janet Eyler, "The Theoretical Roots of Service-Learning in John Dewey: Toward a Theory of Service Learning" Michigan Hournal of Community Service Learning, 1 no. 1 (1994), 78-85.

lvi R.T. Knee, "Service-Learning in Social Work Education: Building Democracy Through Informed Citizenship" (PhD diss., University of Denver, 1999).

lvii J.B. Mabry, "Pedagogical Variations in Service-Learning and Student Outcomes: How Time, Contact and Reflection Matter" Michigan Journal of Community Service Learning, 5 (1998), 32-47.

lviii Mary Besterfield-Sacre, Cynthia Atman, and Larry Shuman, "Characteristics of Freshmen Engineering Students: Models for Determining Student Attrition in Engineering" Journal of Engineering Education, 86, no. 2 (1997), 139149 . 